\title{
The Effectiveness of Online Learning Based on The Complete Sentence Model on Student Learning Outcomes on Theme 2 Sub- Theme 1 in Second Grade Writing Skills
}

\author{
Reni Asri \\ Program Studi Pendidikan Guru Sekolah Dasar, Universitas PGRI Semarang, Semarang, Indonesia \\ e-mail: Reniasri1998@gmail.com \\ Kiswoyo \\ Program Studi Pendidikan Guru Sekolah Dasar, Universitas PGRI Semarang, Semarang, Indonesia \\ e-mail:kiswoyo123@gmail.com \\ Khusnul Fajriyah \\ Program Studi Pendidikan Guru Sekolah Dasar, Universitas PGRI Semarang, Semarang, Indonesia \\ e-mail: khusnulfajriyah@gmail.com
}

\section{A R T I C L E I N F O \\ Article history: \\ 25 December 2020 \\ Received in revised form \\ 01 January 2021 \\ Accepted 25 January 2021 \\ Available online 03 Pebruari 2021 \\ Kata Kunci: \\ Complete Sentence, Menulis, Hasil Belajar \\ Keywords: \\ Complete Sentence, Writing, \\ Learning Outcomes}

\begin{abstract}
A B S T R A K
Kemampuan berbahasa anak menjadi permasalahan yang perlu diperhatikan karena banyak anak yang belum mampu menulis dan menggunakan bahasa yang baik dan benar. Tujuan penelitian ini adalah untuk menganalisis keefektifan pembelajaran daring berbasis model complete sentence terhadap hasil belajar siswa pada Tema 2 Bermain Di Lingkunganku Subtema 1 Bermain Di lingkungan Rumah keterampilan menulis kelas II. Jenis penelitian ini adalah penelitian eksperimen dengan desain penelitian yaitu preexperimental designs. Populasi penelitian adalah kelas II yang terdiri dari 28 siswa tahun pelajaran 2020-2021. Sampel yang diambil adalah siswa kelas kelas II yang terdiri dari 28 siswa dengan menggunakan teknik non probability sampling. Pada penelitian ini teknik analisis data yang digunakan adalah teknik analisis data statistik kuantitatif. Hasil penelitian menunjukkan nilai uji t menunjukkan bahwa hasil perhitungan data nilai peserta didik dengan $t_{\text {hitung }}=1,717804$ dengan harga $t_{\text {tabel }}=1,701113$, maka $t_{\text {hitung }}>$ $t_{\text {tabel }}$. Simpulan penelitian ini adalah terdapat peningkatan yang signifikan, sehingga pembelajaran daring berbasis model complete sentence efektif digunakan terhadap hasil belajar siswa pada Tema 2 Bermain Di Lingkunganku Subtema 1 Bermain Di lingkungan Rumah keterampilan menulis kelas II.
\end{abstract}

\begin{abstract}
A B S T R A C T
Children's language skills are a problem that needs attention because many children are not yet able to write and use good and correct language. The purpose of this study was to analyze the effectiveness of online learning based on the complete sentence model on student learning outcomes in Theme 2 Playing in My Environment Sub-theme 1 Playing in the Home environment writing skills for class II. This type of research is experimental research with a research design that is preexperimental designs. The study population was class II consisting of 28 students for the 2020-2021 school year. The sample taken was class II students consisting of 28 students using nonprobability sampling techniques. In this study, the data analysis technique used is quantitative statistical data analysis techniques. The results showed that the score of the t-test showed that the results of the calculation of the score data of students with $t$ count $=1.717804$ with a price of $t$ table $=1.701113$, then $t$ count $>t$ table. This research concludes that there is a significant increase, so online learning based on the complete sentence model is effectively used for student learning outcomes in theme 2 Playing in My Environment Sub-theme 1 Playing in the Home environment writing skills class II.
\end{abstract}

\section{Introduction}

Education is an effort to increase knowledge and skills through learning and guidance that involves students actively (Idris, 2015; Fitri Kurniasari, 2017; Mayasari \& Ardhana, 2018). Learning is organized to help students gain insight. Along with the development of science and technology, the application of learning also changes. Education in Indonesia is currently implementing the 2013 curriculum.

The 2013 curriculum focuses more on students. Teachers as learning subjects should improve cognitive abilities and student learning activeness, one of which is using a more varied learning model and can be used in online learning. Online learning is learning that uses an internet-based interactive model (Anugrahana, 2020; Fitriyani et al., 2020; Yunitasari \& Hanifah, 2020). Learning takes place online through various applications that 
can be accessed easily. However, with online learning, children's language skills are a problem that needs attention because many children are not yet able to use proper and correct language.

The main language learning is as a communication tool. A child learns language because he is urged by the need to communicate with people in the environment. Humans are social creatures, so humans need to interact with other humans. When humans need their existence, the interaction feels even more important. This interaction activity requires tools, means, or media, language that can be used to demonstrate properly (Anggraeni et al., 2019; Astuti, 2016; Dharmawan et al., 2014).

(F Kurniasari, 2017; Ramadan \& Mulyat, 2020; Suria Oktaviani et al., 2019) States that language skills in the curriculum in schools include four aspects of skills, (1) listening skills, (2) speaking skills, (3) reading skills, (4) and writing skills. These four skills are a unit that is closely related to one another and plays an important role in teaching a language in schools. Of the four aspects mentioned, one of which is writing skills. Writing skills are at the highest level in language skills because writing is a complex activity.

Writing is a complex subject that causes many students to experience difficulty learning to write sentences (Musaffak, 2014; Ramadhani et al., 2016; Rochman, 2013). The teacher only uses the lecture method so that the learning process of writing is less interesting and less fun. By teaching the teacher in a monotonous way, students feel bored and bored and don't listen to explaining the material from the teacher. Many basic processes must be taught happily and thoroughly so that children become happy and understand writing, but teachers often forget these. As a result, student learning outcomes when writing are low and unsatisfactory.

Based on an interview that the researcher conducted on November 25, 2019 with Ms. Tutik Lestari as the second-grade teacher of SD Negeri Bugangan 02 Semarang, teaching students to write is something that is not easy to use for a long time and is extra patient. Based on observations made by researchers on the learning process, many students complained that when online learning was taking place, students seemed lazy to do, and the results of their writing could not be read. After further interviews, the researcher concluded that the students' ability in writing was low due to unsupportive methods. According to the second-grade teacher in teacher learning, they only give examples of writing through video media and student activities only copying writing. With this method, students are still lazy and confused in the process of learning to write. The writing scores can also prove this in grade two, in which most of the students are still low. Of the 28 students, only eight students could write correctly, most of them were still wrong, and there were seven students whose writing could not be read. Students need a lesson that can make them comfortable, happy, and confident in learning to write so that these writing skills can be mastered by students well. Learning must also be beneficial for students and emphasize optimal student involvement (Mahardika, 2018; Puspidalia, 2012; Wahyuni, 2014). One method used is to use the Complete Sentence model.

The complete sentence learning model is a series of learning processes that begins by delivering teaching material by the teacher, or by analyzing the prepared module, dividing groups that cannot be more than three people with heterogeneous abilities, giving worksheets that contain incomplete paragraphs, then allowed students to discuss and end with concluding (Karom et al., 2014; Riana \& Setiadi, 2017; Suparmi, 2013).

(Inapi, 2018; Murwanto, 2020; Purnama \& Aldila, 2016) The complete sentence is a learning strategy that tries to consider students' ability to predict text fragments assigned to them. A complete sentence has a series of learning processes that begin with the delivery of teaching materials by the teacher, analysis of the prepared modules, group division of no more than three people with heterogeneous abilities, giving worksheets containing incomplete descriptions, discussions, and conclusions. So that students can practice writing skills and composing good and correct language.

Research relevant to this research is research conducted by (Purnama \& Aldila, 2016), who get the research results that influence students' mathematical communication skills in cooperative learning model type complete sentences and a team quiz. Research by (Fitriyani et al., 2020), who got the research results during the Covid 19 pandemic, online learning was developed to increase student motivation. Research by (Ulfah \& Soenarto, 2017) gets the research results that video and image media affect rewriting the content of fifth-grade stories.

The purpose of this study was to analyze the effectiveness of online learning based on the complete sentence model on student learning outcomes in Theme 2 Playing in My Environment Sub-theme 1 Playing in the Home environment, second-grade writing skills.

\section{Method}

This research was conducted on second-grade students of SDN Bugangan 02 Semarang, Semarang District, Semarang Regency, Academic Year 2020/2021 online through the WhatsApp group and zoom application. This study uses a Pre-Experimental Design research design in the form of One-Group PretestPosttest Design. Because there is a pre-test before being given treatment, what is then given treatment is learning 
using the complete sentence learning model, then post-test is carried out. Thus, the treatment results can be more accurate because they can compare with the conditions before being treated.

The sample in this study was all grade 2 SDN Bugangan 02 Semarang, totaling 28 students. This study uses the Nonprobability Sampling technique because all members of the population are selected to be the sample. The data collection techniques used in this study were tests, observations, interviews, and documentation. The test instruments were pre-test and post-test. The pre-test and post-test were conducted using 14 multiple-choice questions.

In this study, the data analysis technique used was quantitative statistical data analysis techniques. This technique can be interpreted as a research method used to examine the population or sample. The sampling technique is generally carried out randomly. Data collection uses research instruments. Data analysis is statistical. (Jahring, 2020; Murwanto, 2020; Sumarni, 2016). The data analysis test in this study used the normality test and the t-test, and the completeness test of learning outcomes.

\section{Result and Discussion}

This research was conducted at SDN Bugangan 02 Semarang. Based on the problems in the second grade, researchers are interested in using the complete sentence learning model to overcome these problems. Researchers prepare research instruments and test questions used as a pre-test and post-test questions to measure student learning outcomes after the model is applied. The pre-test and post-test questions consisted of 14 multiple choice questions containing three subjects according to the theme, Indonesian, SBdP, and Mathematics. The results of the pre-test and post-test can be seen in Table 1.

Table 1. Results of the Pretest and Posttest

\begin{tabular}{ccccc}
\hline Type of Test & Total students & Highet Score & Lowest Score & Average \\
\hline Pretest & \multirow{2}{*}{28} & 93 & 42 & 68,46 \\
Posttest & 100 & 79 & 91 \\
\hline
\end{tabular}

Based on Table 1, there is a comparison of scores before and after research. There was a significant increase in the score. As seen in Table 1, the highest pre-test score was 93, and the lowest was 42, with an average pre-test score was 68.5. The highest post-test score was 100 , and the lowest score was 79 , with an average of 91 and all students achieving the Minimum Completion Criteria (KKM). The normality test is carried out after knowing the pre-test and post-test scores, as shown in Table 2.

Table 2. Normality Test Results

\begin{tabular}{lccc}
\hline \multicolumn{1}{r}{ Type of Test } & $\mathbf{L}_{\mathbf{0}}$ & $\mathbf{L}_{\text {Tabel }}$ & Criteria \\
\hline Pretest & 0,9798 & 1,701 & Normal \\
Posttest & 0,7088 & 1,701 & Normal \\
\hline
\end{tabular}

Based on the table above, the results of data calculation from the pre-test score obtained L0 $=0.9798$ with $\mathrm{n}=28$ and the real level $\alpha=0.05$, from the list of critical scores $\mathrm{L}$ it is obtained Ltabel $=1,701$. Because L0 <Ltabel is $0,9798<1.701$, then H0 is accepted so that it can be concluded that the sample comes from a normally distributed population. The data calculation results from the post-test score obtained L0 $=0.7088$ with $\mathrm{n}=28$ and the real level $\alpha=0.05$ from the list of critical scores L obtained Ltabel $=1.701$. Because L0 <Ltabel is $0.7088<1.701$, then $\mathrm{H} 0$ is accepted, so it can be concluded that the sample comes from a normally distributed population.

The criteria for testing $\mathrm{Ha}$ are accepted if tcount> ttable, $\mathrm{n}=28$ with a significant level of 5\%, and for the price tcount $>$ ttable, then $\mathrm{H} 0$ is rejected. After analyzing the data, the score of learning outcomes obtained by an average for the pre-test is 68.5 . The post-test is 91 tcount $=1.717804$ with a significant level of $5 \%$, the score of ttable $=1.701113$ is obtained. Ha is accepted, the Complete Sentence learning model is effective against learning outcomes theme 2 sub-theme 1 writing skills of class II SD Bugangan 02 Semarang. After that, the learning completeness test is carried out, while the results can be seen in Table 3 . 
Table 3. Learning Completeness Test

\begin{tabular}{cccccc}
\hline $\begin{array}{c}\text { Typeof } \\
\text { test }\end{array}$ & Highest Score & Lowest Score & Completed & $\begin{array}{c}\text { Classical } \\
\text { completeness in \% }\end{array}$ & Incomplete \\
\hline Pretest & 93 & 42 & 10 & $36 \%$ & 18 \\
Posttest & 100 & 79 & 28 & $100 \%$ & - \\
\hline
\end{tabular}

Based on table 3, the pre-test results of 28 students show that only 10 students completed with the highest score of 93, and 18 did not complete the KKM with the lowest 42. Meanwhile, in the post-test results, it was found that all students achieved KKM with the highest score of 100 and the lowest score of 79 . The completeness of post-test and pre-test classical learning can be seen in Figure 1.

\section{Ketuntasan Pretest}

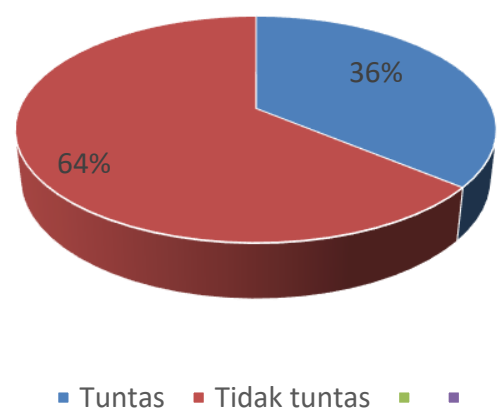

Figure 1. Ketuntasan Pretest

Based on Figure 1, the pre-test results from 28 students showed that only ten students had completed the KKM, 36\%, while 64\% did not complete the pre-test. The completeness of the post-test can be seen in Figure 2.

\section{Ketuntasan Belajar Klasikal Posttest}

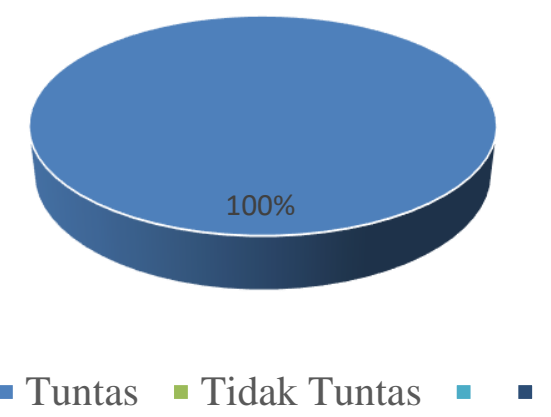

Figure 2. Ketuntasan Posttest

Whereas in Figure 2, the post-test results show that all students can achieve the KKM with the highest score of 100 and the lowest score of 79 . Based on the description above, it can be concluded that there is a significant increase in student learning outcomes on the theme of playing in my environment. that the Complete sentence learning model is effective.

The implementation of this research took place in the second grade of SDN Bugangan 02 Semarang in the academic year 2020/2021. Researchers researched on September 21, 2020. The sample in this study was class two with a total of 28 students. The research begins with compiling research instruments in lesson plans, syllabus, teaching materials, and other learning tools. Researchers conducted research online through the zoom meeting application to convey material and provide directions according to the syntax of the complete sentence learning model. Students are asked to work on the pre-test questions before the researcher applies the complete sentences learning model to determine the differences before and after learning complete sentences. After the material and complete sentence learning was carried out, students were asked to work on the post-test questions 
to determine whether Complete sentence learning was effectively applied to theme 2 playing in my environment, the sub-theme of playing in my home environment.

Student learning outcomes experienced a significant increase after the complete sentence learning model was applied. Students become motivated to improve writing skills because they are presented in various forms. Students are also trained to find words that match the gaps in the complete sentence learning model.

The complete sentence learning model is a series of learning processes that begins by delivering teaching material by the teacher, or by analyzing the prepared module, dividing groups that should not be more than three people with heterogeneous abilities, giving worksheets containing incomplete paragraphs, then allowed students to discuss and end with concluding (Karom et al., 2014; Riana \& Setiadi, 2017; Suparmi, 2013).

Inapi, 2018; Murwanto, 2020; Purnama \& Aldila, 2016, The complete sentence is a learning strategy that tries to consider students' ability to predict text fragments assigned to them. A complete sentence has a series of learning processes that begin with the delivery of teaching materials by the teacher, analysis of the prepared modules, group division of no more than three people with heterogeneous abilities, giving worksheets containing incomplete descriptions, discussions, and conclusions. So that students can practice writing skills and composing good and correct language.

Research relevant to this research is research conducted by (Purnama \& Aldila, 2016), who get the research results that influence students' mathematical communication skills in cooperative learning model type complete sentences and a team quiz. Research by (Fitriyani et al., 2020), who got the research results during the Covid 19 pandemic, online learning was developed to increase student motivation. Research by (Ulfah \& Soenarto, 2017), who get the research results that video and image media affects the skills of rewriting the content of fifth-grade stories.

\section{Conclusion}

Based on data analysis and discussion of the research results, it is concluded that there is a significant increase so that online learning based on the complete sentence model is effectively used for student learning outcomes in Theme 2 Playing in My Neighborhood. Sub-theme 1 Playing at Home, writing skills in second grade.

\section{References}

Anggraeni, R., Sulton, S., \& Sulthoni, S. (2019). Pengaruh Multimedia Tutorial Terhadap Hasil Belajar Bahasa Indonesia. Jurnal Kajian Teknologi Pendidikan, 2(2), 96-101. https://doi.org/10.17977/um038v2i22019p096

Anugrahana, A. (2020). Hambatan, Solusi dan Harapan: Pembelajaran Daring Selama Masa Pandemi Covid-19 Oleh Guru Sekolah Dasar. Jurnal Scholaria, 10(3), 282-289. https://doi.org/10.24246/j.js.2020.v10.i3.p282-289

Astuti, A. P. (2016). Pengembangan Instrumen Penilaian Kompetensi Membaca Pada Mata Pelajaran Bahasa Indonesia Kelas VII BERBASIS QUIPPER SCHOOL. Jinop (Jurnal Inovasi Pembelajaran), 2(2), 334 350. https://doi.org/10.22219/jinop.v2i2.3635

Dharmawan, D. W., Suarjana, I. M., \& Wibawa, I. M. C. (2014). Pengaruh Model Pembelajaran Role Playing Terhadap Keterampilan Berbicara Bahasa Indonesia Kelas V. Mimbar PGSD Undiksha, 2(1). https://doi.org/10.23887/jjpgsd.v2i1.3113

Fitriyani, Y., Fauzi, I., \& Sari, M. Z. (2020). Motivasi Belajar Mahasiswa Pada Pembelajaran Daring Selama Pandemik Covid-19. Jurnal Kependidikan: Jurnal Hasil Penelitian Dan Kajian Kepustakaan Di Bidang Pendidikan, Pengajaran Dan Pembelajaran, 6(2), 165-175. https://doi.org/10.23917/ppd.v7i1.10973

Idris, N. S. (2015). Verba Berendonim Indra Penglihatan Dalam Bahasa Indonesia : Kajian Linguistik Kognitif Dan Semantik Leksikal. Jurnal Pendidikan Bahasa Dan Sastra, 15(1), 11. https://doi.org/10.17509/bs_jpbsp.v15i1.795

Inapi, M. L. (2018). Pengaruh Model Pembelajaran Kooperatif Terhadap Motivasi Dan Hasil Belajar Siswa Pada Materi Sistem Koloid. Pembelajar: Jurnal Ilmu Pendidikan, Keguruan, Dan Pembelajaran, 2(1), 12. https://doi.org/10.26858/pembelajar.v2i1.4135 
Jahring, J. (2020). Kemampuan Koneksi Matematis Pada Model Pembelajaran CORE Dan NHT. Aksioma: Jurnal Program Studi Pendidikan Matematika, 9(1), 182-189. https://doi.org/10.24127/ajpm.v9i1.2667

Karom, D., Ruhimat, T., \& Darmawan, D. (2014). Pengaruh Kompetensi Pedagogik Guru Dalam Menerapkan Pembelajaran Kooperatif Berbantuan Media Presentasi Terhadap Hasil Belajar Peserta Didik Pada Mata Pelajaran Matematika. Edutech, 13(2), 274-308. https://doi.org/10.17509/edutech.v13i2.3113

Kurniasari, F. (2017). Implementasi Pendekatan Saintifik Pada Penugasan Aktivitas Di Buku Teks Bahasa Indonesia Kelas VII SMP Berdasarkan Kurikulum 2013. Jurnal Pendidikan Edutama, 4(1), 9-26. https://doi.org/10.30734/jpe.v4i1.44

Kurniasari, Fitri. (2017). Implementasi Pendekatan Saintifik Pada Penugasan Aktivitas Di Buku Teks Bahasa Indonesia Kelas VII SMP Berdasarkan Kurikulum 2013. Jurnal Pendidikan Edutama, 4(1), 9-26. https://doi.org/10.30734/jpe.v4i1.44

Mahardika, B. (2018). Penerapan Metode Penilaian Berbasis Portofolio Dalam Meningkatkan Pembelajaran Bahasa Indonesia. Elementary: Jurnal Ilmiah Pendidikan Dasar, 4(1), 33-46. https://doi.org/10.32332/elementary.v4i1.1030

Mayasari, D., \& Ardhana, N. R. (2018). Publikasi Bentuk Fungsi dan Kategori SintaksisTuturan Masyarakat Manduro sebagai Pendukung Perkembangan Bahasa Anak Usia Dini. Jurnal Obsesi : Jurnal Pendidikan Anak Usia Dini, 2(1), 54-63. https://doi.org/10.31004/obsesi.v2i1.7

Murwanto, S. (2020). Implementasi Model Pembelajaran Kooperatif Tipe NHT ( Numbered-Head-Together ) untuk Meningkatkan Hasil Belajar IPA Siswa Kelas IX B SMP Negeri 4 Alla Enrekang. Jurnal Sainsmat, 9(1), 14-28. https://doi.org/10.35580/sainsmat91141872020

Musaffak. (2014). Peningkatan Kemampuan Menulis Makalah Mahasiswa Pengambil Matakuliah Bahasa Indonesia Keilmuan Jurusan Pendidikan Bahasa Inggris FKIP UMM Semester II 2012 Dengan Strategi Peta Pikiran. Jurnal Pendidikan Humaniora, 1(4). https://doi.org/10.17977/jph.v1i4.4145

Purnama, I. L., \& Aldila, E. (2016). Kemampuan Komunikasi Matematis Siswa Ditinjau Melalui Model Pembelajaran Kooperatif Tipe Complete Sentence Dan Team Quiz. Jurnal Pendidikan Matematika, 10(1). https://doi.org/10.1.3267.26-41

Puspidalia, Y. S. (2012). Problematika Pembelajaran Bahasa Indonesia Di Mi/Sd Dan Alternatif Pemecahannya. Cendekia: Jurnal Kependidikan Dan https://doi.org/10.21154/cendekia.v10i1.406

Ramadan, S., \& Mulyat, Y. (2020). Makna Kata Dalam Bahasa Indonesia (Salah Kaprah Dan Upaya Perbaikannya). Ranah: Jurnal Kajian Bahasa, 9(1), 90-105. https://doi.org/10.26499/rnh.v9i1.1036

Ramadhani, R., Hs, W., \& Harsiati, T. (2016). Pengembangan Bahan Ajar Keterampilan Berbicara Bahasa Indonesia Bagi Penutur Asing Tingkat Pemula. Jurnal Pendidikan - Teori, Penelitian, Dan Pengembangan, 1(3), 326-337. https://doi.org/10.17977/jp.v1i3.6155

Riana, R., \& Setiadi, S. (2017). Penerapan Model Pembelajaran Kooperatif Teknik Mind Mapping Dalam Meningkatkan Keterampilan Menulis Karangan Narasi Ekspositoris Pada Mata Pelajaran Bahasa Indonesia Peserta Didik Kelas XII Smk Swadaya, Semarang. Jurnal Dinamika Sosial Budaya, 18(1), 109. https://doi.org/10.26623/jdsb.v18i1.562

Rochman, S. (2013). Persepsi Mahasiswa Terhadap Faktor-Faktor Yang Mempengaruhi Sistem Pendidikan Nasional Indonesia (Studi Kasus di Prodi S1 Bahasa dan Sastra Inggris Unsoed. Insania: Jurnal Pemikiran Alternatif Kependidikan, 18(2). https://doi.org/10.24090/insania.v18i2.1463

Sumarni, S. (2016). Upaya Meningkatkan Kemampuan Berhitung Melalui Penerapan Model Pembelajaran Numbered Heads Together Dengan Pemanfaatan Alat Peraga Sederhana Materi Pembagian Siswa Kelas Ii. Refleksi Edukatika : Jurnal Ilmiah Kependidikan, 7(1), 61-68. https://doi.org/10.24176/re.v7i1.1813

Suparmi, S. (2013). Pembelajaran Kooperatif dalam Pendidikan Multikultural. Jurnal Pembangunan Pendidikan: Fondasi Dan Aplikasi, 1(1), 108-118. https://doi.org/10.21831/jppfa.v1i1.1055

Suria Oktaviani, M. D., Suwatra, I. W., \& Murda, N. (2019). Pengaruh Model Pembelajaran Snowball Throwing Berbantuan Media Audiovisual terhadap Hasil Belajar Bahasa Indonesia. Jurnal Ilmiah Sekolah Dasar, 3(1), 89. https://doi.org/10.23887/jisd.v3i1.17662 
Ulfah, D. M., \& Soenarto, S. (2017). Pengaruh penggunaan media video dan gambar terhadap keterampilan menulis kelas V. Jurnal Prima Edukasia, 5(1), 22-34. https://doi.org/10.21831/jpe.v5i1.7693

Wahyuni, S. (2014). Pengembangan Interactive E-Book Bidang Asesmen Bahasa Untuk Mengembangkan Kompetensi Dan Kemandirian Mahasiswa Program Pendidikan Bahasa. Litera, 13(1), 128-139. https://doi.org/10.21831/1tr.v13i1.1908

Yunitasari, R., \& Hanifah, U. (2020). Pengaruh Pembelajaran Daring terhadap Minat Belajar Siswa pada Masa Covid 19. Edukatif: Jurnal Ilmu Pendidikan, 2(3), 236-240. https://doi.org/10.31004/edukatif.v2i3.142 